\title{
Jatropha curcas Disease Identification using Random Forest
}

\author{
Triando Hamonangan Saragih ${ }^{1}$, Vivi Nur Wijayaningrum ${ }^{2}$, Muhammad Haekal ${ }^{3}$ \\ ${ }^{1,3}$ Computer Science Lambung Mangkurat University, Jalan A. Yani Km 36, Banjarbaru 70714, Indonesia \\ ${ }^{2}$ Department of Information Technology, Politeknik Negeri Malang, Jalan Soekarno Hatta 9, Malang 65145, Indonesia
}

\begin{abstract}
ARTICLE INFO
\section{Article histories:}

Received February 27, 2021

Revised March 17, 2021

Accepted March 24, 2021

\section{Keywords:}

Classification;

Decision tree;

Disease;

Expert system;

Jatropha curcas;

Random-forest

\section{ABSTRACT}

As one of the most versatile plants, Jatropha curcas is spread in various regions around the world because of the great benefits it provides. However, Jatropha curcas is easily attacked by viruses which then cause damage to the plant, such as yellowing leaves and secreting sap, making it necessary to identify Jatropha curcas disease to deal with the problem as early as possible so that the losses incurred are not too large. An expert system was built to be able to identify Jatropha curcas disease by adopting expert knowledge. The use of the Random Forest algorithm as one of the classification algorithms was applied in this study. By using a random forest, several disease prediction classes are generated by each decision tree that has been formed. The disease class with the most votes was used as the final result. In this study, the data used were 166 data with 9 diseases and 30 symptoms. The results showed that Random Forest outperformed other algorithms such as Fuzzy Neural Network and Extreme Learning Machine with an accuracy of $98.002 \%$ using the composition of training data and test data of 70:30.
\end{abstract}

This work is licensed under a Creative Commons Attribution-Share Alike 4.0

\section{Vivi Nur Wijayaningrum,}

Department of Information Technology, Politeknik Negeri Malang, Jalan Soekarno Hatta 9, Malang 65145, Indonesia Email: vivinurw@polinema.ac.id

\section{INTRODUCTION}

Jatropha curcas is a versatile plant that is often used as a wound medicine, and its leaves are used for drinking against malaria. Then these plants can also be used to prevent erosion, control soil degradation, and increase soil fertility [1]. In recent years, Jatropha curcas has been quite popular because of its function as a potential source of vegetable oil as a substitute for petroleum and, in particular, biodiesel production [2]. There have been several studies on this plant as a substitute for biofuels. Nowadays, Jatropha curcas can be traded as raw material for the treatment of various diseases, such as cancer, skin diseases, respiratory diseases, and infectious diseases [3].

There are many kinds of diseases that attack Jatropha curcas can degrade the quality of the resulting Jatropha curcas [4]. The lack of experts and farmers' knowledge about Jatropha curcas delivers negative outcomes to Jatropha curcas. Issues that aren't finished as quickly as a viable terrible effect on the quality of Jatropha curcas. This problem may be helped using an expert system. An expert system is a system that adopts expert knowledge is then fed right into a computer, after which the computer can offer solutions to issues like an expert.

Making an expert system to solve these problems can be done in various ways, such as using Fuzzy Neural Network [5], Optimized Fuzzy Neural Network [6], Extreme Learning Machine [7], and Optimized Extreme Learning Machine [8]. Fuzzy Neural Network that has been done by Saragih et al. provide an average accuracy of $11.2 \%$ using 30 symptoms and 9 diseases [5]. Then, Fajri et al. made improvements by optimizing the Fuzzy Neural Network using Simulated Annealing so that it provides an average accuracy of 32.5\%, better than previous research [6]. However, the computational complexity in the fuzzy defuzzification process is usually very high [9], so that in 2018, the Extreme Learning Machine algorithm was used by Saragih et al. to identify Jatropha curcas disease with an average accuracy of $60.61 \%$ [7]. In the same year, Saragih et al. performed an optimization on Extreme Learning Machine using Modified Simulated Annealing and produced a good average 
accuracy of $90,955 \%$. However, the computation time required is quite high compared to the use of other algorithms beforehand [8].

The problem of disease identification can be solved by using classification [10]. One of the classification algorithms that can provide high accuracy is Random Forest. In previous research conducted by Farnaaz and Jabbar, Random Forest was used for Network Intrusion Detection and resulted in low false alarm rates and high detection rates [11]. Random Forest has also been successfully used to predict rainfall in anticipation of flooding with an accuracy of $99.45 \%$ [12]. In other studies that have been conducted by Thomas and Chandra on cognitive level classification, the use of Random Forest is able to provide high recommendations for elearning content based on the level of difficulty [13]. Even in other studies, Random Forest was able to provide $100 \%$ accuracy for predicting schizophrenia, even though the training data used was only $40 \%$ of the total data [14]. Several studies that have been done before prove that Random Forest can produce high accuracy because of its ability to reduce error values due to bias and variance [15].

The use of Random Forest to solve problems in the health sector is quite popular and produces good accuracy. This is because Random Forest is able to increase accuracy through the mechanism of random decision making and voting, without any correlation between each decision tree [14], so the application of Random Forest for disease identification can be maximized with results resembling expert decisions. Therefore, in this study, Random Forest is used to identifying Jatropha curcas disease with the hope that this system can be an alternative for disease identification. Thus, the community can independently identify Jatropha curcas by observing the symptoms as a first step before seeing a doctor or plant disease expert.

\section{RESEARCH METHOD}

The main objective of this research is to identify Jatropha curcas disease based on the symptoms found in each plant. An expert system was designed by applying Random Forest as a classification algorithm to determine the type of disease in Jatropha curcas. The proposed system for identifying Jatropha curcas disease is shown in Fig. 1.

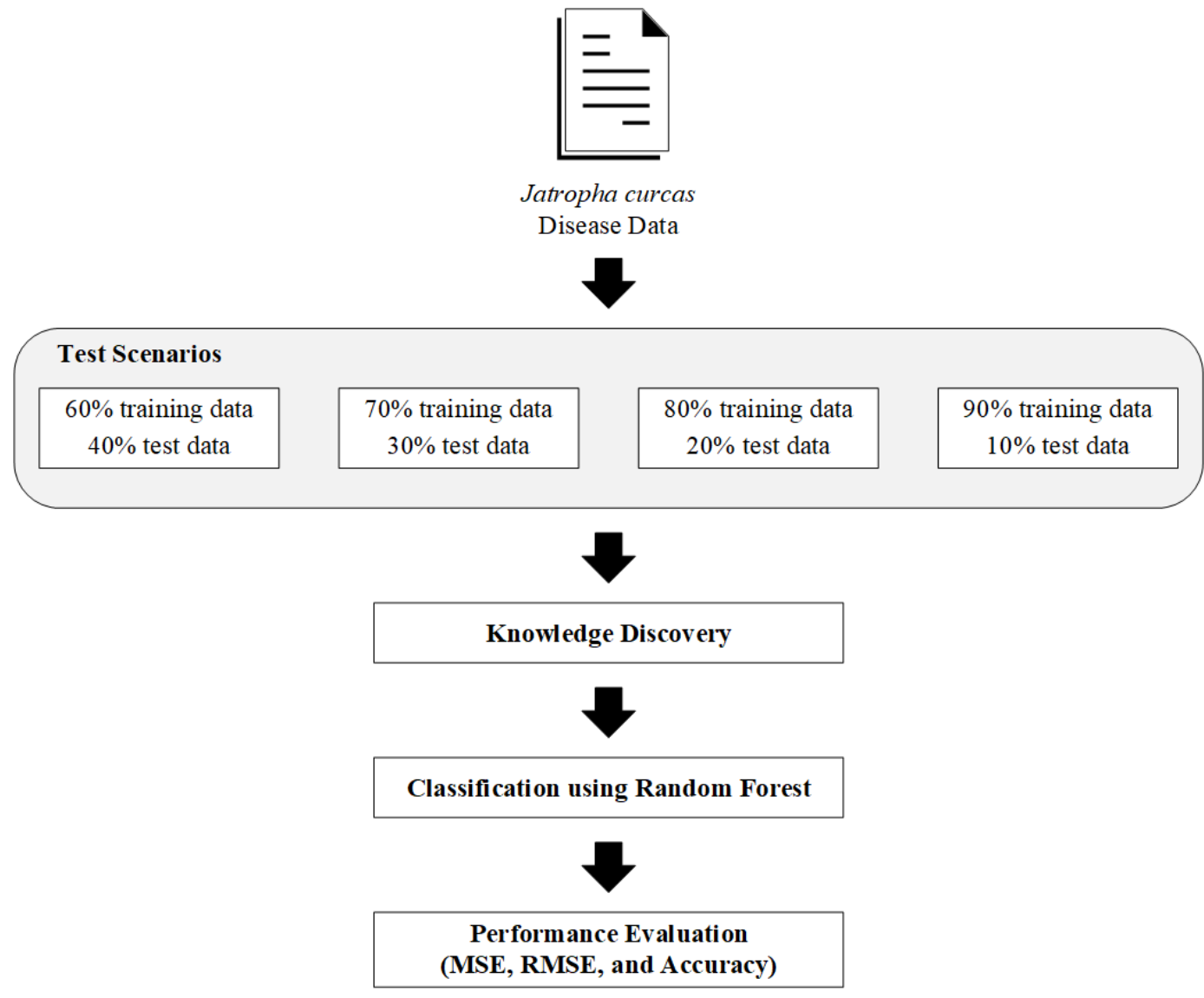

Fig. 1. The proposed system architecture 


\subsection{Data Collection}

Jatropha disease arises because of a living pathogen [4]. There are many varieties of pathogenic fungi that attack the Jatropha plant, such as Helminthosporium tetramera, Pestalotiopsis paraguarensis, $P$. Vesicolor, Cercospora jatrophaecurces, Phytophthora spp., Pythium spp., Fusarium spp., Dothiorella sp., Colletotrichum sp., Oidium sp., Alternaria sp., Fusarium sp., Xanthomonas sp., J. Gossypiellap, and Armillaria tabescens [16]. These pathogenic varieties cause various diseases, such as leaf spots, root rot, and others. Information about Jatropha disease and some of its symptoms can be seen in Table 1 [4].

Table 1. Symptoms and Causes of Jatropha Disease

\begin{tabular}{|c|c|c|c|c|}
\hline No & Diseases & Pathogen & Symptoms & Causes \\
\hline 1 & $\begin{array}{l}\text { Bacterial } \\
\text { Wilt }\end{array}$ & $\begin{array}{l}\text { Ralstonia } \\
\text { solanacearum } \\
\text { Bacteria }\end{array}$ & $\begin{array}{l}\text { Infected plants become } \\
\text { withered. }\end{array}$ & $\begin{array}{l}\text { - Rot at the base of the stem and roots. } \\
\text { - The other side of the plant withers. } \\
\text { - Experiencing decay at the base of the } \\
\text { branch. } \\
\text { - The main stem base sometimes rots. }\end{array}$ \\
\hline 2 & $\begin{array}{l}\text { Charcoal } \\
\text { Roat }\end{array}$ & $\begin{array}{l}\text { Rhiczoctonia } \\
\text { bataticola Fungi }\end{array}$ & $\begin{array}{l}\text { May cause sprouts to die } \\
\text { before or after surface. }\end{array}$ & $\begin{array}{l}\text { - The leaves wither in all parts of the } \\
\text { plant suddenly. } \\
\text { - The leaves wither yellowing at the } \\
\text { bottom of the plant and fall out. } \\
\text { - Root looks blackish. }\end{array}$ \\
\hline 3 & $\begin{array}{l}\text { Powdery } \\
\text { Mildew }\end{array}$ & $\begin{array}{l}\text { Pseudoidium } \\
\text { jatrophae Fungi }\end{array}$ & $\begin{array}{l}\text { - Leaf fall or shoot } \\
\text { does not develop and } \\
\text { die. } \\
\text { - Young fruits usually } \\
\text { change shape and } \\
\text { fall. }\end{array}$ & $\begin{array}{l}\text { The presence of white powdery mildew } \\
\text { on the leaves, fruit, and stems when they } \\
\text { are still young or shoot. }\end{array}$ \\
\hline 4 & Antraknosa & $\begin{array}{l}\text { Colletotrichum } \\
\text { gloeosporioides } \\
\text { Fungi }\end{array}$ & $\begin{array}{l}\text { Leaves or fruit } \\
\text { become damaged. } \\
\text { - }\end{array}$ & $\begin{array}{l}\text { - Brown round spots are restricted } \\
\text { yellow halo. } \\
\text { - If attacking the edge of the leaves are } \\
\text { irregular spots. } \\
\text { - Blackish brown spots on the fruit } \\
\text { surface }\end{array}$ \\
\hline 5 & $\begin{array}{l}\text { Bacterial } \\
\text { Blight }\end{array}$ & $\begin{array}{l}\text { Xanthomonas } \\
\text { campestris. }\end{array}$ & & $\begin{array}{l}\text { - Aqueous spots bordering leaf repeats } \\
\text { to form angled spots. } \\
\text { - Blackish spots on the leaves. } \\
\text { - Under the surface, leaves look shiny }\end{array}$ \\
\hline 6 & $\begin{array}{l}\text { Fusarium } \\
\text { Wilt }\end{array}$ & $\begin{array}{l}\text { Fusarium spp. } \\
\text { Fungi }\end{array}$ & Plants become dead & $\begin{array}{l}\text { - Plant withered with yellowish leaves. } \\
\text { - If the stem is defended will look like } \\
\text { the part of the woody brown ribbed. }\end{array}$ \\
\hline 7 & Dieback & Not yet known & & $\begin{array}{l}\text { - The rot starts from the tip/top of the } \\
\text { plant. } \\
\text { - Leaves fall, and stems look bare. } \\
\text { - Side shoots cannot grow because the } \\
\text { branches rot. } \\
\text { - The rotten part is usually watery, and } \\
\text { the shoots dry out. } \\
\text { - If the split part will be seen the vessels } \\
\text { and brown pith. }\end{array}$ \\
\hline 8 & $\begin{array}{l}\text { Cercospora } \\
\text { Leaf Blight }\end{array}$ & $\begin{array}{l}\text { Cercospora } \\
\text { jatrophicola } \\
\text { Fungi }\end{array}$ & & Irregular brown color on leaves. \\
\hline 9 & $\begin{array}{l}\text { Altenaria } \\
\text { Leaf Blight }\end{array}$ & Altenaria Fungi & & Spots ring rounded leaves \\
\hline
\end{tabular}

The type of data used in this study consisted of training data and test data. The training data were obtained from experts in Jatropha plant disease at Indonesian Sweetener and Fiber Crops Research Institute, Situbondo. The data were obtained from direct interviews conducted in 2015. The data used consisted of 166 observation cases. Each of these cases has various types of symptoms and disease classes that have been determined by the 
expert. The information obtained is 9 Jatropha disease and 30 symptoms with a value of each symptom between $0-1$. From the 166 data that have been obtained, the dataset will be divided into training data and test data through a series of tests to determine the composition of the training data and test data that can provide the highest accuracy disease identification results.

\subsection{Random Forest}

The principle of the Random Forest is to make decisions based on a series of decisions in the form of a decision tree. In Random Forest, there are a number of individual decision trees that generate their respective predictive classes. The class with the most votes will be the prediction class as the final result. The structure of the Random Forest can be seen in Fig. 2.

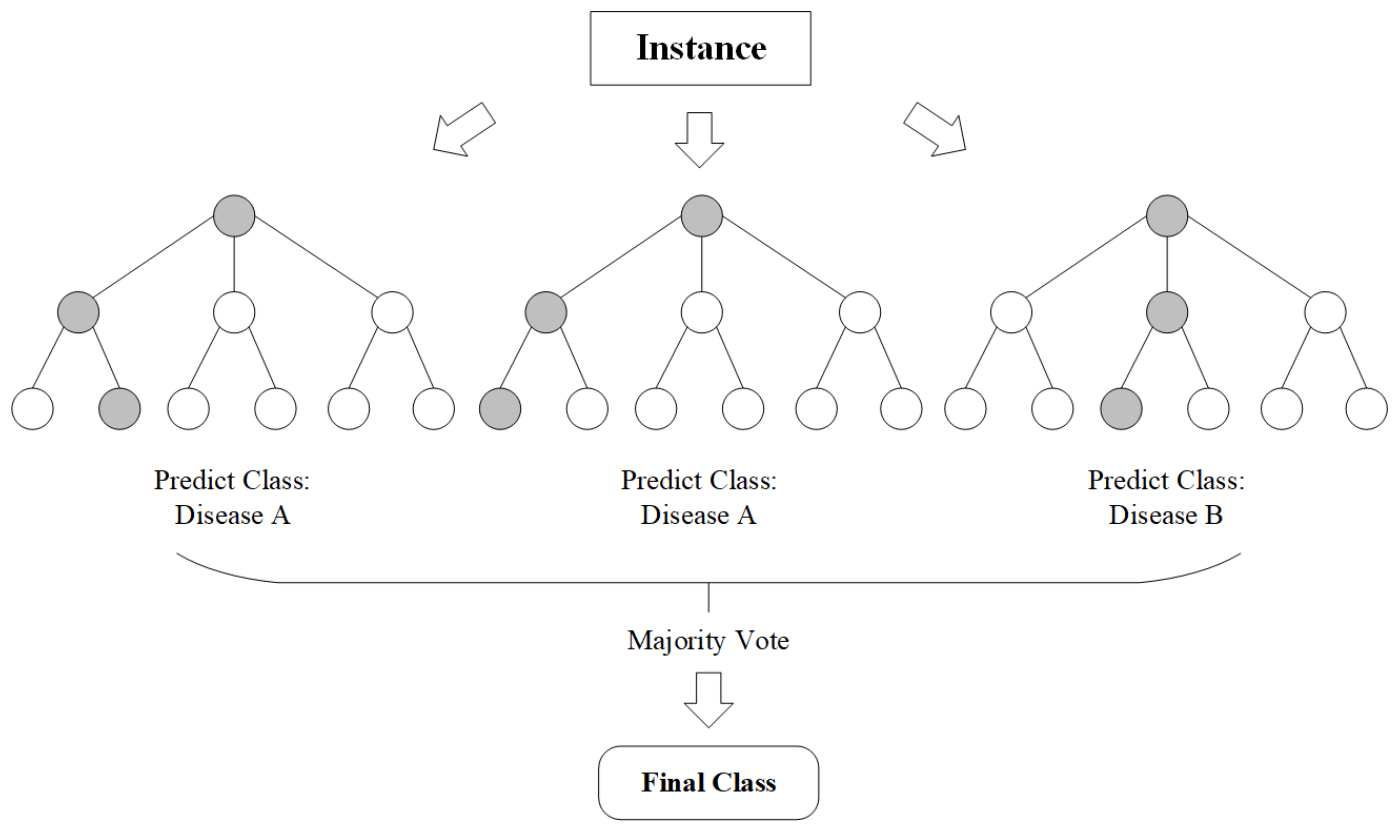

Fig. 2. Structure of Random Forest

To form a Random Forest model, there are two methods that can be used, namely bagging and random subspace. The following are the steps for developing the Random Forest model [17]:

1. Perform randomly resampling with the same size as the training data using the bootstrapping method

2. Choose $\mathrm{K}$ attributes from the total $\mathrm{M}$ attributes where $\mathrm{K}<\mathrm{M}$ using random subspace method, usually the value of $\mathrm{K}$ is equal to the square root of $\mathrm{M}$

3. Form a decision tree using bootstrap samples and attributes that have been previously selected

4. Repeat steps 1 through 3 to shape the tree up to the desired number. The number of trees in Random Forest is determined based on the out-of-bag error rate (OOB)

\subsection{Assessment Indices}

To evaluate the classification results for the identification of Jatropha disease, this study used three assessment indices, namely Mean Square Error (MSE), Root Mean Square Error (RMSE), and Accuracy. The existence of the assessment index aims to measure the success rate of the system, as well as make it easier to make comparisons with other algorithms.

MSE measures the error rate by calculating the difference between the squares of the average estimated value and the actual value. Meanwhile, RMSE is used to measure the difference in the value (sample or population) of the predicted results and the observed value. The MSE and RMSE formulas are shown in (1) and (2).

$$
M S E=\frac{1}{n} \sum_{i=1}^{n}\left(y_{i}-\hat{y}_{i}\right)^{2}
$$




$$
R M S E=\sqrt{\sum_{i=1}^{n} \frac{\left(y_{i}-\hat{y}_{i}\right)^{2}}{n}}
$$

In (1) and (2), $y$ is the actual value, $\hat{y}$ is the predicted value, and $n$ is the number of test data.

Accuracy is used to measure the degree of closeness of the predicted value to the actual value. The calculation of accuracy is shown in (3).

$$
\text { Accuracy }=\frac{\text { Correct classified }}{\text { Total classified }}
$$

\section{RESULTS AND DISCUSSION}

Several tests were carried out to determine the composition of the amount of training data and test data that could give good results based on MSE, RMSE, and accuracy. The composition of training data and test data used in this study were 60:40, 70:30, 80:20, and 90:10. For each experimental scenario with these compositions, the experiment was carried out ten times, and then the average value was calculated. The results of the first test for the composition of training data and test data of 60:40 are shown in Table 2 .

Table 2. Experimental results for $60 \%$ training data and $40 \%$ test data

\begin{tabular}{cccc}
\hline Testing & MSE & RMSE & Accuracy \\
\hline 1 & 0.052093 & 0.22824 & 0.9672 \\
2 & 0.05493 & 0.234371 & 0.9672 \\
3 & 0.052303 & 0.228698 & 0.9836 \\
4 & 0.051123 & 0.226105 & 0.9672 \\
5 & 0.052564 & 0.229268 & 0.9508 \\
6 & 0.051668 & 0.227307 & 0.9672 \\
7 & 0.052876 & 0.229949 & 0.9672 \\
8 & 0.052066 & 0.228179 & 0.9672 \\
9 & 0.051548 & 0.227041 & 0.9836 \\
10 & 0.05308 & 0.230391 & 0.9672 \\
\hline Average & 0.052425 & 0.228955 & 0.96884 \\
\hline
\end{tabular}

In Table 2, it can be seen that the composition of $60 \%$ training data and $40 \%$ test data provides a fairly good accuracy with a fairly small error value, namely an accuracy of $96.884 \%$, MSE 0.052425 , and RMSE 0.228955 . Furthermore, the results of the second test for the composition of the training data and the test data of 70:30 are shown in Table 3.

Table 3. Experimental results for $70 \%$ training data and $30 \%$ test data

\begin{tabular}{cccc}
\hline Testing & MSE & RMSE & Accuracy \\
\hline 1 & 0.051544 & 0.227033 & 0.9778 \\
2 & 0.050619 & 0.224987 & 0.9778 \\
3 & 0.05109 & 0.226031 & 0.9778 \\
4 & 0.053147 & 0.230535 & 0.9778 \\
5 & 0.053157 & 0.230559 & 0.9778 \\
6 & 0.051752 & 0.227491 & 0.9778 \\
7 & 0.051799 & 0.227594 & 0.9778 \\
8 & 0.050146 & 0.223934 & 0.9778 \\
9 & 0.050684 & 0.225132 & 1 \\
10 & 0.050735 & 0.225245 & 0.9778 \\
\hline Average & 0.051467 & 0.226854 & 0.98002 \\
\hline
\end{tabular}

In Table 3, it can be seen that the composition of $70 \%$ training data and $30 \%$ test data provides slightly better accuracy compared to the previous test results, namely an accuracy of $98.002 \%$, MSE 0.051467 , and RMSE 0.226854. Furthermore, the results of the third test for the composition of the training data and the test data of 80:20 are shown in Table 4. 
Table 4. Experimental results for $80 \%$ training data and $20 \%$ test data

\begin{tabular}{cccc}
\hline Testing & MSE & RMSE & Accuracy \\
\hline 1 & 0.0527 & 0.0527 & 0.9333 \\
2 & 0.0548 & 0.0527 & 0.9667 \\
3 & 0.055962 & 0.0527 & 0.9333 \\
4 & 0.053943 & 0.0527 & 1 \\
5 & 0.05593 & 0.0527 & 0.9333 \\
6 & 0054754 & 0.0527 & 0.9333 \\
7 & 0.054072 & 0.0527 & 0.9333 \\
8 & 0.053236 & 0.0527 & 0.9667 \\
9 & 0.055035 & 0.0527 & 0.9333 \\
10 & 0.05369 & 0.0527 & 0.9333 \\
\hline Average & 0.054412 & 0.0527 & 0.94665 \\
\hline
\end{tabular}

Table 4 shows that the composition of $80 \%$ of the training data and $20 \%$ of the test data provides worse accuracy than the test results of the two previous scenarios, namely an accuracy of $94.665 \%$, MSE 0.054412 , and RMSE 0.0527. Finally, the results of testing the composition of the training data and the 90:10 test data are shown in Table 5.

Table 5. Experimental results for $90 \%$ training data and $10 \%$ test data

\begin{tabular}{cccc}
\hline Testing & MSE & RMSE & Accuracy \\
\hline 1 & 0.071472 & 0.267343 & 0.9375 \\
2 & 0.073608 & 0.271308 & 0.875 \\
3 & 0.07138 & 0.267169 & 0.9375 \\
4 & 0.072502 & 0.269262 & 0.875 \\
5 & 0.068382 & 0.2615 & 0.9375 \\
6 & 0.068506 & 0.261737 & 0.9375 \\
7 & 0.072966 & 0.270121 & 0.9375 \\
8 & 0.072363 & 0.269005 & 0.9375 \\
9 & 0.07402 & 0.272066 & 0.875 \\
10 & 0.076032 & 0.275738 & 0.875 \\
\hline Average & 0.072123 & 0.268525 & 0.9125 \\
\hline
\end{tabular}

The test results in Table 5 show that the resulting accuracy, MSE, and RMSE values are the worst compared to the other test scenarios, with smaller accuracy values and larger error values. This shows that the composition of the training data and test data affects the classification results given. Increasing the number of training data causes the bias to increase and the variance to decrease. In general, the more training data, the lower the error rate because the variance decreases. However, more training data does not guarantee that the accuracy will increase because the bias will also increase, causing underfitting, which is failure to obtain important information on the dataset so that the model formed has high loss and produces low accuracy.

To clarify the understanding of all test scenario results, three graphs are provided that illustrate the comparison of the test results for all scenarios based on MSE, RMSE, and accuracy. Graphs showing the average accuracy of MSE, RMSE, and accuracy for all test scenarios that have been carried out are presented in Fig. 3 to Fig. 5.

Fig. 3 to Fig. 5 show the variation of MSE, RMSE, and accuracy values for all tests. Based on Fig. 3, it can be seen that the best composition to provide the lowest MSE value is 70\% training data and 30\% test data with an MSE of 0.51467423. Furthermore, the lowest RMSE value in Fig. 4 is produced when the composition of the training data and test data is $80 \%$ and $20 \%$, with an RMSE of 0.05270026 . While the best accuracy value based on the graph in Fig. 5 is produced when the composition of the data used is $70 \%$ and $30 \%$ for training data and test data with an accuracy of $98.002 \%$. 


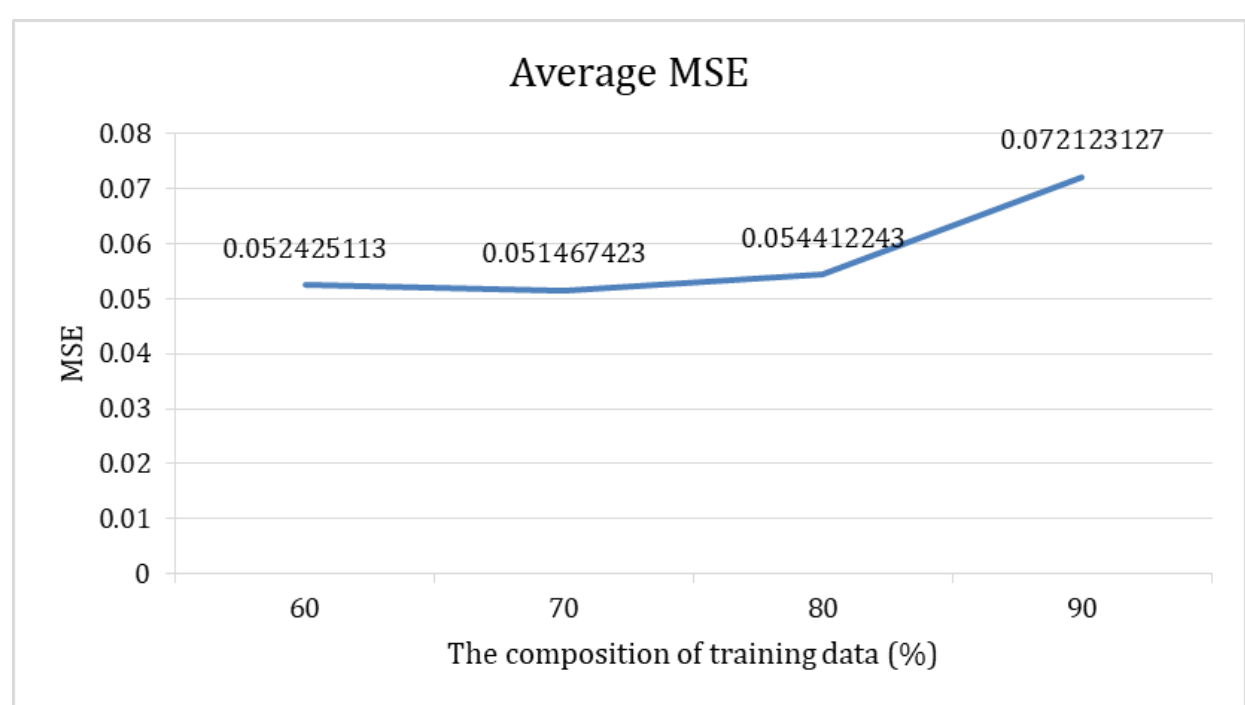

Fig. 3. Graph of average MSE for all test scenarios

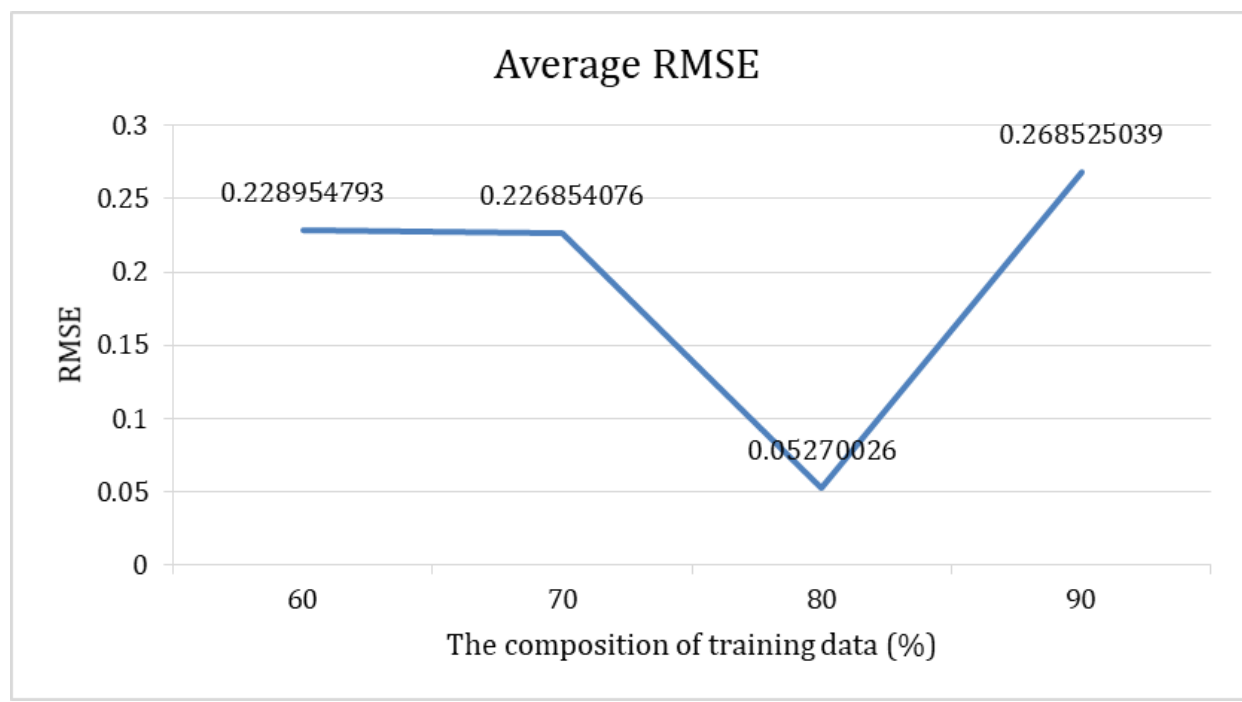

Fig. 4. Graph of average RMSE for all test scenarios

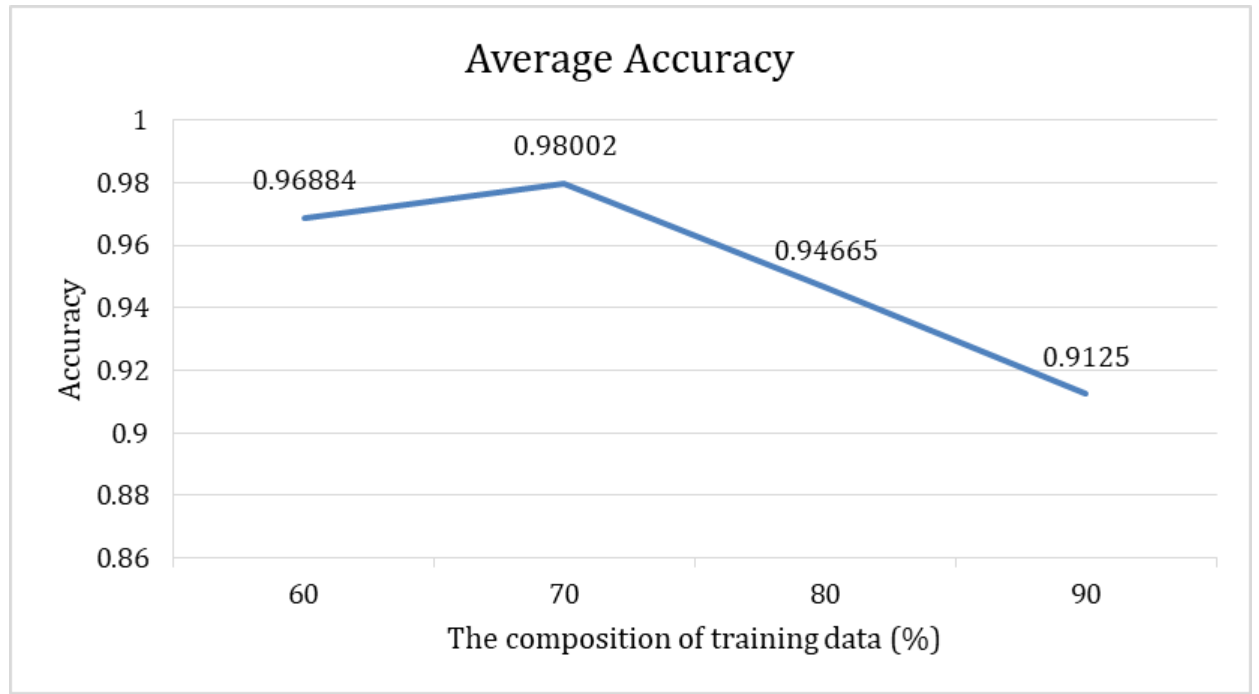

Fig. 5. Graph of average accuracy for all test scenarios 
Comparison of accuracy with other studies was also conducted to measure the performance of Random Forest to identify Jatropha curcas disease. In this test, the composition of the training data and test data used is 70:30 to fit the comparative study. Table 6 shows the comparison of the accuracy values of several algorithms that have been used previously for the same case, as well as the Random Forest used in this study. Previous studies did not provide information on MSE and RMSE.

Table 6. Comparison of MSE, RMSE, and accuracy with other algorithms

\begin{tabular}{lccc}
\hline \multicolumn{1}{c}{ Algorithms } & MSE & RMSE & Accuracy \\
\hline Fuzzy Neural Network [5] & Not Provided & Not Provided & 11.2 \\
Optimized Fuzzy Neural Network [6] & Not Provided & Not Provided & 32.5 \\
Extreme Learning Machine [7] & Not Provided & Not Provided & 60.61 \\
Optimized Extreme Learning Machine [8] & Not Provided & Not Provided & 90.955 \\
Random Forest & 0.051467 & 0.226854 & 98.002 \\
\hline
\end{tabular}

Based on the comparison results shown in Table 6, it can be seen that Random Forest gives better results than previous studies to solve cases of Jatropha curcas disease identification. This is because Random Forest forms a large number of non-correlated decision trees so that it is able to identify important variables or features in the dataset used as input. The high accuracy given by Random Forest can make consideration for its application in real systems.

\section{CONCLUSION}

Based on the test results, it can be concluded that the composition of the training data and test data has an influence on the classification or prediction results, which is marked by changes in accuracy and error rate. The test results also show that Random Forest is able to outperform other algorithms that have been used to solve the problem of Jatropha curcas disease identification with an accuracy of $98.002 \%$ using the composition of training data and test data of 70:30. This proves that the use of Random Forest can be applied to real systems.

In future studies, the tuning parameters in the Random Forest can be used to improve the results of even better accuracy. This can be done using optimization algorithms such as Simulated Annealing [18]-[20], Particle Swarm Optimization [21], or Genetic Algorithm [22]-[24]. In addition, the use of deep learning can also be considered to determine the effect it has on the accuracy, MSE, and RMSE [25][26].

\section{REFERENCES}

[1] W. F. Abobatta, "Jatropa curcas: an overview," J. Adv. Agric., vol. 10, pp. 1650-1656, 2019. https://doi.org/10.24297/jaa.v10i0.8145

[2] A. J. King, W. He, J. A. Cuevas, M. Freudenberger, D. Ramiaramanana, and I. A. Graham, "Potential of Jatropha curcas as a source of renewable oil and animal feed," J. Exp. Bot., vol. 60, no. 10, pp. 2897-2905, 2009. https://doi.org/10.1093/jxb/erp025

[3] H. A. Abdelgadir and J. Van Staden, "Ethnobotany, ethnopharmacology and toxicity of Jatropha curcas L. (Euphorbiaceae): A review," South African J. Bot., vol. 88, pp. 204-218, 2013. https://doi.org/10.1016/j.sajb.2013.07.021

[4] T. Yulianti and N. Hidayah, Jatropha Curcas Disease. Malang: Balai Penelitian Tanaman Pemanis dan Serat, 2015.

[5] T. H. Saragih, D. M. N. Fajri, A. Hamdianah, W. F. Mahmudy, and Y. P. Anggodo, "Jatropha Curcas Disease Identification Using Fuzzy Neural Network," in International Conference on Sustainable Information Engineering and Technology (SIET), Batu, Indonesia, 25-25 November, 2017. https://doi.org/10.1109/SIET.2017.8304153

[6] D. M. N. Fajri, T. H. Saragih, A. Hamdianah, W. F. Mahmudy, and Y. P. Anggodo, "Optimized Fuzzy Neural Network for Jatropha Curcas Plant Disease Identification," in International Conference on Sustainable Information Engineering and Technology (SIET), Batu, Indonesia, 25-25 November, 2017. https://doi.org/10.1109/SIET.2017.8304152

[7] T. H. Saragih, D. M. N. Fajri, W. F. Mahmudy, A. L. Abadi, and Y. P. Anggodo, "Jatropha Curcas Disease Identification with Extreme Learning Machine,” Indones. J. Electr. Eng. Comput. Sci., vol. 12, no. 2, pp. 883-888, 2018. https://doi.org/10.11591/ijeecs.v12.i2.pp883-888

[8] T. H. Saragih, W. F. Mahmudy, A. L. Abadi, and Y. P. Anggodo, "Application of extreme learning machine and modified simulated annealing for jatropha curcas disease identification," Int. J. Adv. Soft Comput. its Appl., vol. 10, no. 2, pp. 108-119, 2018.

[9] C. J. Lin, S. Y. Jeng, H. Y. Lin, and C. Y. Yu, "Design and Verification of an Interval Type-2 Fuzzy Neural Network Based on Improved Particle Swarm Optimization," Appl. Sci., vol. 10, no. 9, pp. 3041, 2020. https://doi.org/10.3390/app10093041

[10] M. Abdar, E. Nasarian, X. Zhou, G. Bargshady, V. N. Wijayaningrum, and S. Hussain, "Performance improvement of decision trees for diagnosis of coronary artery disease using multi filtering approach," in 2019 IEEE 4th International Conference on Computer and Communication Systems (ICCCS), 2019, pp. 26-30. https://doi.org/10.1109/CCOMS.2019.8821633 
[11] N. Farnaaz and M. A. Jabbar, "Random Forest Modeling for Network Intrusion Detection System," Procedia Comput. Sci., vol. 89, pp. 213-217, 2016. https://doi.org/10.1016/j.procs.2016.06.047

[12] A. Primajaya and B. N. Sari, "Random Forest Algorithm for Prediction of Precipitation," Indones. J. Artif. Intell. Data Min., vol. 1, no. 1, pp. 27-31, 2018. https://doi.org/10.24014/ijaidm.v1i1.4903

[13] B. Thomas and C. J., "Random forest application on cognitive level classification of E-learning content," Int. J. Electr. Comput. Eng., vol. 10, no. 4, pp. 4372, Aug. 2020. https://doi.org/10.11591/ijece.v10i4.pp4372-4380

[14] Z. Rustam and G. S. Saragih, "Prediction schizophrenia using random forest," TELKOMNIKA (Telecommunication, Comput. Electron. Control., vol. 18, no. 3, pp. 1433-1438, 2020. https://doi.org/10.12928/telkomnika.v18i3.14837

[15] A. Clim, R. Zota, R. Constantinescu, and I. Ilie-Nemedi, "Health services in smart cities: Choosing the big data mining based decision support," Int. J. Healthc. Manag., vol. 13, no. 1, pp. 79-87, 2020. https://doi.org/10.1080/20479700.2019.1650478

[16] K. Anitha and K. S. Varaprasad, "Jatropha Pests and Diseases: An Overview," in Jatropha, Challenges for a New Energy Crop, 2012, pp. 175-218. https://doi.org/10.1007/978-1-4614-4806-8_10

[17] X. Zhou, P. Lu, Z. Zheng, D. Tolliver, and A. Keramati, "Accident Prediction Accuracy Assessment for HighwayRail Grade Crossings Using Random Forest Algorithm Compared with Decision Tree,” Reliab. Eng. Syst. Saf., vol. 200, pp. 106931, 2020. https://doi.org/10.1016/j.ress.2020.106931

[18] L. M. R. Rere, M. I. Fanany, and A. M. Arymurthy, "Simulated Annealing Algorithm for Deep Learning," Procedia Comput. Sci., vol. 72, pp. 137-144, 2015. https://doi.org/10.1016/j.procs.2015.12.114

[19] G. A. F. Alfarisy, A. N. Sihananto, T. N. Fatyanosa, M. S. Burhan, and W. F. Mahmudy, "Hybrid Genetic Algorithm and Simulated Annealing for Function Optimization," J. Inf. Technol. Comput. Sci., vol. 1, no. 2, pp. 82-97, 2017. https://doi.org/10.25126/jitecs.20161215

[20] T. Sousa, T. Soares, H. Morais, R. Castro, and Z. Vale, "Simulated Annealing to Handle Energy and Ancillary Services Joint Management Considering Electric Vehicles," Electr. Power Syst. Res., vol. 136, pp. 383-397, 2016. https://doi.org/10.1016/j.epsr.2016.03.031

[21] E. Purnamasari, D. P. Rini, and Sukemi, "The Combination of Naive Bayes and Particle Swarm Optimization Methods of Student's Graduation Prediction," J. Ilm. Tek. Elektro Komput. dan Inform., vol. 5, no. 2, pp. 112-119, 2019. https://doi.org/10.26555/jiteki.v5i2.15272

[22] W. Lesmawati, A. Rahmi, and W. F. Mahmudy, "Optimization of Frozen Food Distribution Using Genetic Algorithm," J. Environ. Eng. Sustain. Technol., vol. 03, no. 01, pp. 51-58, 2016. https://doi.org/10.21776/ub.jeest.2016.003.01.7

[23] Q. Kotimah, W. F. Mahmudy, and V. N. Wijayaningrum, "Optimization of Fuzzy Tsukamoto Membership Function using Genetic Algorithm to Determine the River Water," Int. J. Electr. Comput. Eng., vol. 7, no. 5, pp. 2838-2846, 2017. https://doi.org/10.11591/ijece.v7i5.pp2838-2846

[24] I. Wahyuni and W. F. Mahmudy, "Rainfall Prediction in Tengger, Indonesia Using Hybrid Tsukamoto FIS and Genetic Algorithm Method," J. ICT Res. Appl., vol. 11, no. 1, pp. 38-55, Apr. 2017. https://doi.org/10.5614/itbj.ict.res.appl.2017.11.1.3

[25] A. A. Candel, Arno, Viraj Parmar, Erin LeDell, "Deep learning with H2O,” H2O. ai Inc, October, 2016.

[26] I. Cholissodin and S. Sutrisno, "Prediction of rainfall using improved deep learning with particle swarm optimization," TELKOMNIKA (Telecommunication Comput. Electron. Control., vol. 18, no. 5, pp. 2498, Oct. 2020. https://doi.org/10.12928/telkomnika.v18i5.14665

\section{BIOGRAPHY OF AUTHORS}

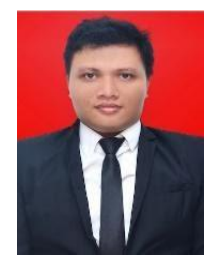

Triando Hamonangan Saragih is a lecturer in Department of Computer Science, Lambung Mangkurat University. His research interest is centered on Data Science.

Email: triando.saragih@ulm.ac.id

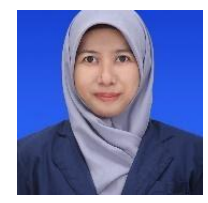

Vivi Nur Wijayaningrum is a lecturer in Department of Information Technology, Politeknik Negeri Malang. Her research interest is centered on Computational Intelligence.

Email: vivinurw@polinema.ac.id

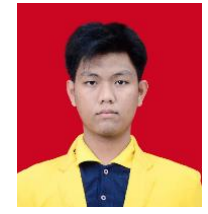

Muhammad Haekal is an undergraduate student in the Department of Computer Science, Lambung Mangkurat University. His research interest is centered on Bioinformatics.

Email: muhammadhaekal77@gmail.com 